\title{
Can the aim of belief ground epistemic normativity?
}

\author{
Charles Côté-Bouchard ${ }^{1}$
}

Published online: 14 March 2016

(C) The Author(s) 2016. This article is published with open access at Springerlink.com

\begin{abstract}
For many epistemologists and normativity theorists, epistemic norms necessarily entail normative reasons. Why or in virtue of what do epistemic norms have this necessary normative authority? According to what I call epistemic constitutivism, it is ultimately because belief constitutively aims at truth. In this paper, I examine various versions of the aim of belief thesis and argue that none of them can plausibly ground the normative authority of epistemic norms. I conclude that epistemic constitutivism is not a promising strategy for grounding epistemic normativity.
\end{abstract}

Keywords Epistemic normativity - Aim of belief - Epistemic norms - Epistemic reasons · Normativity · Epistemic constitutivism · Constitutivism · Normativism

\section{Epistemic norms and epistemic normativity}

Epistemology, many think, is about what we should or should not believe. It is, in other words, about epistemic norms, i.e. the norms that specify the epistemic or truth-related conditions under which we are required or permitted to believe things. ${ }^{1}$

\footnotetext{
1 Let me make three clarifications. First, I actually take epistemic norms to govern doxastic attitudes, i.e. not only belief, but also disbelief and withholding or suspension of belief. I only mention belief in what follows for simplicity. Second, using 'epistemic norms' to denote only epistemic norms of belief is not strictly correct. Plausibly, there are also epistemic norms governing other things like assertion and treating something as a reason. I therefore take 'epistemic norms' to be short for 'epistemic norms of belief' in this paper. Finally, I take 'epistemic' in 'epistemic norms' to mark not only that these norms govern beliefs - as opposed to actions and non-doxastic attitudes—but also that they govern beliefs from
}

Charles Côté-Bouchard

charles.cote79@gmail.com

$1 \quad$ King's College London, London, UK 
While some maintain, for example, that we should only believe what is true or what we know, others claim that believing falsehoods is permissible as long we have adequate evidence for them. ${ }^{2}$ In what follows, I set the content of epistemic norms aside however and focus instead on their normative force or authority.

While all norms trivially set standards relative to which certain things are required, permitted, good, and the like, not all of them have necessary normative force. If a norm $\mathrm{N}$ forbids $\varphi$-ing under conditions $\mathrm{C}$, then trivially, $\varphi$-ing under $\mathrm{C}$ is forbidden, incorrect, wrong, or bad relative to the standard set by $\mathrm{N}$. However, the descriptive, norm-relative question of what is permitted or required according to $\mathrm{N}$ is distinct from the normative question of what there is good or genuinely normative reasons to do. ${ }^{3}$ For any norm $\mathrm{N}$, you can very well recognize that $\mathrm{N}$ says you should not $\varphi$ under $\mathrm{C}$ and still ask whether there is any good reason to do as $\mathrm{N}$ says. ${ }^{4}$

Plausibly, most norms are such that the answer to this normative question could be 'no'. For most norms, in other words, there could be situations in which there is no good reason for you to $\varphi$ even though these norms ask you to $\varphi$. Philippa Foot famously illustrated this using the example of etiquette:

[...] one may reasonably ask why anyone should bother about what should-e, (should from the point of view of etiquette) be done, and that such considerations deserve no notice unless reason is shown. So although people give as their reason for doing something the fact that it is required by etiquette, we do not take this consideration as in itself giving us reason to act. Considerations of etiquette do not have any automatic reason-giving force, and a man might be right if he denied that he had reason to do "what's done" (Foot 1972, 309).

\section{Similarly, Richard Joyce writes:}

Consider Celadus the Thracian, an unwilling gladiator: he's dragged off the street, buckled into armor, and thrust into the arena. [...] Let's imagine that there are various rules of gladiatorial combat: you ought not throw sand in your opponent's eyes, for instance. [...] Imagine that things are looking bleak-his opponent is a sadistic professional fighter, and Celadus finds himself pinned down and swordless. His only hope is to throw some sand in his rival's eyes. (Let's stipulate, with utter implausibility, that he can get away with nobody seeing him do this, just as a way of being sure that there will be

\footnotetext{
Footnote 1 continued

a distinctly epistemic or truth-related point of view - as opposed to, say, a moral or prudential point of view. Thus, I leave open the question whether epistemic norms also determine what we should or should not believe all things considered and whether there can be non-epistemic norms of belief.

2 See e.g. Littlejohn and Turri (2014) for recent work on epistemic norms.

3 I use 'good reasons' and 'genuinely normative reasons' interchangeably in what follows. I say more on these qualifications below.

4 I borrow the phrase 'normative question' from Korsgaard (1996) and Broome (2013). The term 'normrelativity' is from Hattiangadi (2007). Other labels used in the literature for the same distinction include, for instance, rule-implying versus reason-implying normativity (Parfit 2011), formal versus robust normativity (McPherson 2011), and weak versus strong categoricity (Joyce 2001).
} 
no negative repercussions in the form of punishment for breaking the rules.) The rules still say that Celadus shouldn't do it, but he doesn't care about the rules - he has no particular reason to follow them, and every reason to reject them. Given that he has never entered into any form of contract to follow the rules, and that following the rules will lead to his quick and unjust demise, I think we will all agree that Celadus ought to throw sand in his opponent's eyes (Joyce 2001, 34-35).

We could multiply the examples. Plausibly, there is not automatically a good reason to conform to norms of fashion, gender stereotypes, tradition, religious sects, the Sicilian Mafia code of conduct, and so on. The point is that most norms do not seem to necessarily entail or provide good reasons to do as they say.

For many normativity theorists however, some norms do have necessary normative force. It is widely held, for instance, that moral norms necessarily entail good or genuinely normative reasons. ${ }^{5}$ What about epistemic norms? Do they have necessary normative force like, perhaps, moral norms? Many epistemologists and normativity theorists think so. More precisely, many hold what I will call Epistemic Normativity:

\section{(Epistemic Normativity) Epistemic norms necessarily entail good reasons; there is necessarily a good reason to conform to epistemic norms. ${ }^{6}$}

My goal in this paper is not to defend or reject Epistemic Normativity. Instead, I would like to examine a particular kind of strategy for grounding or explaining it, i.e. a particular kind of answer to the question: why or in virtue of what do epistemic norms necessarily entail good reasons? ${ }^{7}$ The strategy is what I will call epistemic constitutivism (EC). According to EC, Epistemic Normativity is true ultimately in

\footnotetext{
5 Why qualify reasons in this way? Just like 'require', 'should', 'correct', 'right', and so on, 'reasons' can be read in a descriptive, norm-relative way. All norms can be said to entail what could be called normrelative reasons. So in a descriptive norm-relative sense, even norms like those of etiquette or fashion entail reasons, namely etiquette reasons and fashion reasons. These norm-relative reasons are just the considerations that favour $\varphi$-ing according to or from the point of view of these norms. Thus another way to formulate the point I make in this section is that you can very well recognize the descriptive fact that some consideration is a reason to $\varphi$ relative to $\mathrm{N}$ (i.e. a $\mathrm{N}$-relative reasons or $\mathrm{N}$-reason), but still ask the further normative question whether this $\mathrm{N}$-reason has genuine normative force, i.e. whether this $\mathrm{N}$-reason constitutes a good reason. Moreover, many think that some norms are such that the reasons they entail are necessarily good ones. For example, moral reasons - the considerations that are reasons from the point of view of moral norms - are widely thought to necessarily be good reasons. Note however that this is not the same as the claim that what morality requires is necessarily what we should do all things considered. Many think that even though moral norms necessarily entail good reasons, such reasons can be outweighed by other considerations. The distinction is rather between norms that necessarily entail good pro tanto reasons and those that do not.

${ }^{6}$ In other words, just like moral reasons, epistemic reasons-the considerations that constitute reasons from the point of view of epistemic norms - are necessarily good reasons. Epistemic Normativity is widely defended or taken for granted in contemporary normativity theory and epistemology. In addition to proponents of the strategy I criticize below, see for instance Scanlon (1998), Kelly (2003), Cuneo (2007), Skorupski (2010), Raz (2011), and Parfit (2011).

7 See Grimm (2009) for an overview of the issue of grounding epistemic normativity.
} 
virtue of the fact that belief constitutively aims at truth. ${ }^{8}$ For epistemic constitutivists, in other words, the popular thesis that belief constitutively aims at truth - the aim of belief thesis for short-is ultimately all we need to vindicate the necessary normative force of epistemic norms. ${ }^{9}$

In what follows, I argue that EC is hopeless. I start by clarifying the epistemic constitutivist strategy in Sect. 2. I then examine the main possible interpretations of the aim of belief thesis-i.e. the functional interpretation (Sect. 3), the personal interpretation (Sect. 4), and the normativist interpretation (Sect. 5) — and argue that none of them can ground Epistemic Normativity. I conclude in Sect. 6 that epistemic constitutivism fails. We should either look for a different strategy for explaining the necessary normative force of epistemic norms or abandon Epistemic Normativity altogether.

\section{Epistemic constitutivism}

Epistemic constitutivism (EC) is a particular instance of a more general strategynormative constitutivism (NC) - for grounding the necessary normative force of norms. ${ }^{10} \mathrm{NC}$ typically starts with the claim that a certain activity, attitude, or kind of being $\mathrm{X}$ has a constitutive aim $\mathrm{A}$, the attaining of which necessarily requires or involves conforming to some norms $\mathrm{N}$. Roughly, to say that an aim A is constitutive of $\mathrm{X}$ is to say that part of what it is for something to be an instance of $\mathrm{X}$ is for it to be directed or regulated towards attaining A. So something cannot count as an instance of $\mathrm{X}$ unless it aims at $\mathrm{A}$ in some sense. The strategy is then to point out that $\mathrm{X}$-ing or

\footnotetext{
${ }^{8}$ Or some other truth-related or epistemic goal such as knowledge, evidential support, coherence, and the like. I remain neutral regarding what belief aims at exactly. I only use truth as my example in this paper for simplicity and because it is the most popular candidate. See for instance Williams (1973), Railton (1994, 1997), Velleman (2000), Wedgwood (2002), Boghossian (2003), Shah (2003), Burge (2003), Millar (2004), Gibbard (2005), Shah and Velleman (2005), Steglich-Petersen (2006, 2009), Vahid (2006), Whiting (2010, 2012), and Littlejohn (2012). Knowledge is the most popular alternative. See Peacocke (1999), Williamson (2000), Adler (2002), Engel (2004), Bird (2007), Sutton (2007), Huemer (2007), McHugh (2011), and Littlejohn (2013). For an overview of issues surrounding the aim of belief thesis, see McHugh and Whiting (2014) and Fassio (2015). Note that many of these authors claim that truth or knowledge is the constitutive norm of belief. In this paper, I follow Wedgwood (2002) and take this normativist claim to be one possible interpretation of the aim of belief thesis. I return to normativism below.

9 Velleman (2000), Wedgwood (2002), Shah and Velleman (2005), O'Hagan (2005), Steglich-Petersen (2009), and Tubert (2010). See Railton (1997) and Papineau (2013) for criticism. It is worth noting that some constitutivists focus exclusively on epistemic or theoretical rationality. That is, they only attempt to ground reasons to be epistemically or theoretically rational. This way of framing the issue is problematic however since it is not obvious that the requirements of epistemic rationality exhaust epistemic norms and what we epistemically should believe. After all, for many normativity theorists-e.g. Scanlon (1998), Parfit (2011), and Broome (2013) — what is most rational for you to do in general is not necessarily what you should or have most normative reasons to do. Similarly, some think that the epistemically rational thing to believe is not necessarily what we epistemically should believe. See for instance Kolodny (2005), Littlejohn (2012), Broome (2013), Sylvan (2014), and Worsnip (Forthcoming). Hence, it cannot be assumed that grounding the normative force of epistemic rationality would be sufficient for grounding Epistemic Normativity.

${ }^{10}$ See Tubert (2010) for an overview of normative constitutivism.
} 
being $\mathrm{X}$ is inescapable for creatures like us. But since we cannot escape $\mathrm{X}$ and since $\mathrm{X}$ necessarily involves aiming at $\mathrm{A}$, aiming at $\mathrm{A}$ is inescapable for us. Moreover, since attaining this unavoidable aim requires or involves conforming to norms $\mathrm{N}$, it follows that $\mathrm{N}$ necessarily has normative force for us. Constitutivism is popular in the practical domain. Many claim, for instance, that we can ground practical or even moral normativity in what is constitutive of action or agency. ${ }^{11}$

One important motivation for adopting normative constitutivism is, roughly, that it promises to vindicate inescapable or necessary normativity without positing any metaphysically and epistemologically problematic facts. As such, it offers an attractive alternative to both nonnaturalist normative realism and normative error theory. Nonnaturalists claim that there are genuinely normative facts, but that they cannot be identified or reduced to natural facts. ${ }^{12}$ Error theorists agree that necessary or inescapable normativity would require the existence of sui generis nonnatural facts, but argue that there are no such facts and therefore that there is no such thing as necessary or inescapable normativity. ${ }^{13}$ Constitutivism is attractive because it promises the best of both worlds, namely genuine necessary normativity without mysterious entities. The key, constitutivists think, is to ground normativity in facts that are themselves necessary but not mysterious, i.e. in constitutive features of inescapable things like agency and belief.

One complication is that constitutivism is often construed as a strategy for grounding the content of norms. Christine Korsgaard, for example, argues that constitutive features of agency not only ground the normative force of morality, but also determine in part what morality requires. ${ }^{14} \mathrm{We}$ should therefore distinguish normative constitutivism from what could be called norm-constitutivism, i.e. constitutivist strategies for deriving necessary constraints on the content of norms. As I explained above, for any norm $\mathrm{N}$, you can always recognize the fact that $\mathrm{N}$ asks you to $\varphi$, but still ask the normative question whether there is any good reason to do as $\mathrm{N}$ says. Hence, even if we derived the content of $\mathrm{N}$ via a constitutivist strategy, this would not suffice to settle the normative question with respect to N. My target in this paper is only epistemic constitutivism understood as an instance of normative constitutivism. Thus, my rejection of EC leaves open the possibility of deriving the content of epistemic norms from the constitutive aim of belief.

One could demur at this point and claim that grounding norms is sufficient for grounding normativity. One could claim, in other words, that normative reasons are nothing over and above norm-relative reasons, and that normativity is nothing over and above norm-relativity. ${ }^{15}$ There is no space to properly evaluate this suggestion here. However, note that if it were true, then all we would have to do in order to

\footnotetext{
11 Velleman (2000), Wallace (2001), Rosati (2003), O’Hagan (2004, 2005), Ferrero (2009), Korsgaard (1996, 2008, 2009), Tubert (2010, 2011), Bertea (2013), and Katsafanas (2013), (Forthcoming). See Enoch (2006) for criticism.

12 E.g. Moore (1903), Scanlon (1998), Shafer-Landau (2003), Wedgwood (2007), Fitzpatrick (2008), Parfit (2011), and Enoch (2011).

13 E.g. Mackie (1977), Garner (1990), Joyce (2001), and Olson (2014).

14 Korsgaard (1996, 2008, 2009).

15 See Tiffany (2007) and Finlay (2014) for discussion.
} 
generate reasons to $\varphi$ would be to come up with norms - any norms we like - that tell us to $\varphi$. But this is counter-intuitive. Intuitively, normative reasons to $\varphi$ are considerations that justify or count in favour of $\varphi$-ing. But plausibly, the sole fact that $\varphi$-ing is required by a norm-whatever the norm-does not justify or favour $\varphi$ ing to any extent. After all, norms can be arbitrary, absurd, immoral, selfdestructive, etc. Relative to the norm or standard of successful serial killing, for example, there are reasons (serial killing-reasons) to murder as many people as possible without getting caught. But plainly, the mere fact that this horrible course of action is required by some norm does not make it justified to any extent. ${ }^{16}$ In any case, I put this issue aside in what follows and argue that assuming that there is a distinction between norm-relativity and genuine normativity, epistemic constitutivism fails as an instance of normative constitutivism.

As I mentioned above, EC starts with the claim that belief constitutively aims at truth. That is, part of what it is for something to be a belief is for it to be, in some sense, directed or regulated towards being true. Since epistemic norms specify truthrelated conditions under which we are required or permitted to believe propositions, attaining the aim of belief plausibly involves or requires conforming to epistemic norms. ${ }^{17}$ Crucially however, belief seems inescapable for beings like us. As Railton explains:

An agent acts on intentions and plans, which constitutively involve beliefs and are formed deliberatively in part on the basis of beliefs. To replace all belief with (say) wishing would be to form no intentions at all. Moreover, our notion of ourselves as agents extended over time constitutively involves memories and expectations. These, too, involve beliefs. [...] To delete all forms of belief from your mental repertoire would leave you with no recognizable notion of identity. Being "in the belief business" [...] is a precondition of agency (Railton 1997, 58-59).

Since beliefs are necessarily involved in essential components of agency, it follows that we necessarily believe things and thus that we cannot avoid the aim of truth.

According to EC, these are all the ingredients we need in order to vindicate Epistemic Normativity. Eric Wiland summarizes the strategy as follows:

[T] he nature of belief tells us something about reasons for belief. [...] The justification for believing the truth doesn't come from something external to the nature of belief itself. [...] Rather, if you are even in the business of believing things, you thereby have reason to believe what's true. Truth is the constitutive aim of belief, and so reasons to believe are necessarily related to considerations concerning what's believed (Wiland 2012, 117).

\footnotetext{
16 Perhaps the present suggestion is best interpreted not as an identification of normativity with normrelativity, but rather as the claim that there is really no such thing as genuine normativity. If so, then it is compatible with the claim of this paper. If there is no genuine normativity, then the aim of belief thesis cannot ground the claim that epistemic norms necessarily entail genuinely normative reasons since there are no such reasons.

${ }^{17}$ I will assume that it does.
} 
Similarly, Asbjørn Steglich-Petersen writes:

[A]im theorists hope to explain the norms of epistemic justification governing belief. Beliefs ought not merely to be true-they also ought to be formed in ways that ensure or make it likely that they are true. A natural explanation of such epistemic norms is that following them promotes the aim of believing truly. [...] The aim theory promises, in other words, a simple, unified, and prima facie unproblematic explanation of epistemic normativity (SteglichPetersen 2009, 396).

Since attaining the aim of truth requires or involves conforming to epistemic norms and since we cannot possibly avoid the aim of truth, epistemic constitutivists conclude that epistemic norms necessarily have normative force for us.

Is EC plausible? Importantly, there are several possible ways to interpret the claim that belief constitutively aims at truth and different interpretations of the aim of belief thesis yield correspondingly different versions of EC. In the remainder of this paper, I consider the main possible interpretations of the aim of belief thesis and argue that none of them can plausibly ground Epistemic Normativity.

\section{The functional interpretation}

On one interpretation, to claim that belief constitutively aims at truth is to claim that being true is the constitutive function or purpose of belief. ${ }^{18}$ Alexander Bird, for instance, suggests that "[c]ognitive faculties have essential functions, as do bodily organs and the like. The function of the liver is to filter toxic impurities out the blood. Likewise, the function of the faculty of belief is to produce truth/knowledge (depending which you think the aim is). ${ }^{19}$ Belief constitutively aims at truth, in other words, in the same sense that the liver constitutively aims at filtering toxic impurities out the blood. Just like a liver only functions properly if it filters the impurities out the blood, belief only functions properly if it is true. ${ }^{20}$ This is necessarily the case since having this function or purpose is part of what it is for something to be a belief.

Can such a functional interpretation of the aim of belief thesis ground Epistemic Normativity? According to Epistemic Normativity, there is necessarily a good reason to do as epistemic norms say. Therefore, Epistemic Normativity only follows if:

\footnotetext{
18 See e.g. Velleman (2000), Burge (2003), Bird (2007), and McHugh (2012).

19 Bird (2007, 94).

20 This is a simplification. As the passage from Bird indicates, proponents of the functional interpretation often understand it as the idea that mechanisms, faculties, or systems of belief-formation and revision have the constitutive function of producing true beliefs. Another possible formulation is that the constitutive function or purpose of the process or activity of belief-formation and revision is to produce true belief. Thus, a belief-forming mechanism or an instance belief-formation fulfils its constitutive purpose only if it produces true beliefs. My vague characterization of truth being the constitutive function of belief should be read as encompassing those possible more precise formulations. The arguments below are meant to apply to the functional version of EC regardless of the more precise characterization of the functional aim of belief thesis.
} 
(RFB) There is necessarily a good reason to have properly functioning beliefs.

This raises a question: what grounds this additional normative claim? Is RFB also true in virtue of the fact that belief has a constitutive function?

Epistemic constitutivists must answer 'yes' because answering 'no' would mean abandoning their view. Since RFB is a necessary step between the function of belief and Epistemic Normativity, what grounds it will also ground Epistemic Normativity. So if RFB is not grounded in the aim of belief, then neither is Epistemic Normativity. Epistemic constitutivists cannot ground RFB, for example, in the fact that malfunctioning beliefs are always bad for us or that properly functioning beliefs are always intrinsically valuable. If they did, it would be these value claims that would ultimately ground Epistemic Normativity and not the fact that truth is the function of belief.

So can the fact that truth is the constitutive function of belief itself ground RFB? The analogy with organs raises an initial worry with the idea. Plausibly, our organs have functions and we have good reasons to have properly functioning organs. But intuitively, this not in virtue of the very fact that they have these functions. Rather, it seems to be because e.g. having properly functioning organs is good for us or because we want to avoid illness, suffering, death, etc.

One possible answer is that normativity does follow from functions since functions entail ought claims and value claims. If the function of the liver is to filter impurities out the blood, then it seems to follow that qua livers, livers ought to filter impurities out the blood and that livers that do not do so are bad qua liver. Likewise, if beliefs fulfil their function only if they are true, does it not follow that beliefs ought to be true and that false beliefs are necessarily bad qua beliefs?

But the sole fact that false beliefs are bad qua beliefs does not entail that there is any good reason to avoid them. All it entails is norm-relativity, not genuine normativity. We can very well recognize that beliefs ought not to be false relative to the standard set by their function, but still ask whether there is any good reason to conform to this function-relative ought. For all the functional aim of belief says, there could be situations where there is just no good reason to have a wellfunctioning belief.

To see this, consider other things which have constitutive functions or purposes. If function-relative oughts and values alone entailed genuine normativity, there would necessarily be a good reason for anyone engaged in an aim-governed activity to fulfil the purpose of that activity. But this is implausible. Activities like torture or hired killing have constitutive functions or purposes, which also entail functional ought-claims and value-claims. Torturers ought qua torturers to make their victims suffer as intensely as possible and for as long as possible without causing them to pass out. Similarly, hired killers ought qua hired killers to murder their victims quickly without leaving a trace. But obviously, that does not mean that there is automatically a good reason for torturers and hired killers to do these things. If it did, then simply taking up the role of torturer or hired killer would suffice to give you a good reason to torture and murder. Relatedly, if being engaged in an aimgoverned activity sufficed to generate good reasons to attain that activity's purpose, there would be an implausibly easy way to generate good reasons to attain any aim 
$A$ : we would simply have to create activities-e.g. games-with $A$ as its constitutive aim and then engage in these activities.

A possible response is that these examples are irrelevant because they are examples of activities with bad purposes or functions. Belief is different, one might say, because true beliefs are always instrumentally or finally good. ${ }^{21}$ This move is not available to epistemic constitutivists however since it would mean grounding Epistemic Normativity in the value of true belief rather than in the fact that belief aims at truth. ${ }^{22}$ The problem, more generally, is that it does not seem possible to explain why there is automatically a good reason to fulfil the function of belief, but not that of torture or hired killing, without invoking factors beyond the sole fact that truth is the constitutive function of belief.

Another possible reply is that unlike torture or hired killing, forming and revising beliefs is part of what it is to be an agent. So the claim that EC relies on is not that there is necessarily a reason to fulfil the constitutive function of whatever activity we engage in, but rather:

(RFA) There is necessarily a good reason to fulfil the purpose of activities that are constitutive of agency.

But why think that being constitutive of agency makes a normative difference? It cannot just be because it makes these activities unavoidable. Unavoidability is not normatively relevant. The fact that you cannot help $\varphi$-ing does not bear on whether there is any good reason for you to $\varphi$. The fact that an alcoholic cannot help binge drinking, for example, does not provide any justification for her binge drinking. Similarly, suppose it turned out that all human agents are necessarily e.g. selfish or cruel under certain circumstances. That by itself would not make selfishness and cruelty in these circumstances justified or right to any extent. At the very least, even if we recognized that such selfishness and cruelty are necessary features of agency, we could still legitimately ask whether there is any good reason to be selfish or cruel under these circumstances.

Neither can it be because there is necessarily a good reason to be an agent or because being an agent is necessarily a good thing. At best, this would entail that there is necessarily a reason to have beliefs, but not to always have properly functioning ones. Systematic conformity to epistemic norms is not necessary for agency. Agents can very well have beliefs that are epistemically irrational, unjustified, incorrect, and so on. Perhaps one cannot count as an agent without having at least some properly functioning beliefs. But this would only entail that there is a good reason to have some properly functioning beliefs, which clearly falls short of Epistemic Normativity.

For all these reasons, I conclude that the claim that truth is the constitutive function of belief cannot plausibly ground Epistemic Normativity.

\footnotetext{
21 Thanks to an anonymous referee for raising this point.

22 One alternative suggestion is that to say that belief aims at truth just is to say that true beliefs are necessarily good. I take this to fall under the normativist interpretation, which I examine below.
} 


\section{The personal interpretation}

The problem with the functional version of EC was that it could not plausibly bridge the gap between the constitutive aim of belief and what there is good reasons for us to do. Epistemic constitutivists cannot plausibly explain why there is necessarily a reason for us to have properly functioning beliefs without going beyond the sole fact that truth is the constitutive function of belief. One tempting way around this problem is to locate the constitutive aim of belief instead at the personal level and view it as an aim that agents themselves necessarily possess. The functional interpretation locates the truth aim at the sub-personal level since it views it as an aim that, in a sense, our beliefs or belief-forming mechanisms themselves have. This leaves open the question whether at the personal level, agents themselves aim at fulfilling belief's constitutive aim or function.

According to the personal interpretation of the aim of belief thesis however, to say that belief constitutively aims at truth is to say that we necessarily aim at believing the truth whenever we form or revise beliefs. ${ }^{23}$ This is a potential solution to the above problems because for many authors, normativity and good reasons are grounded in our aims or desires. This view of normativity goes by many names, but $\mathrm{I}$ will refer to it as reasons internalism. ${ }^{24}$ For reasons internalists, whenever a consideration $\mathrm{C}$ is a genuinely normative reason for $\mathrm{S}$ to $\varphi, \mathrm{C}$ has this normative force, roughly, in virtue of the fact $S$ has an aim that would be served by $\varphi$-ing. The personal version of EC is best seen as relying on reasons internalism. ${ }^{25}$ If the truth aim of belief is one that agents necessarily have and if possessed aims can ground good reasons, then Epistemic Normativity might very well follow.

Reasons internalism is, of course, highly controversial. For one thing, it entails that simply having an aim-no matter how immoral or self-destructive-can suffice to generate good reasons to pursue that aim. But there is certainly something counter-intuitive in the claim that one could get good reasons murder, steal, humiliate, torture, and so on, just by aiming at accomplishing these acts or by wanting something that requires performing these acts. I will leave this worry aside however since even if we accept reasons internalism, the personal reading of the aim of belief thesis is untenable. The claim that we necessarily aim at believing the truth whenever we form beliefs is implausible.

On one reading, aims are intentions. To aim at $\varphi$-ing or to have the aim of $\varphi$-ing is to intend to $\varphi$. Given the personal interpretation of the aim of belief, this would entail that we necessarily intend to believe the truth about whether $\mathrm{P}$ whenever we

\footnotetext{
23 This distinction between the functional or sub-personal interpretation and the personal interpretation is analogous to Vahid's (2006) distinction between doxastic and epistemic goals, i.e. between beliefs aiming at truth and aiming at true beliefs.

24 Other labels include, for instance, subjectivism, neo-Humeanism, instrumentalism, and desire-based theories. For various versions of reasons internalism, see e.g. Williams (1979), Smith (1994), Schroeder (2007), Goldman (2009), and Markovits (2014).

25 The more general view that epistemic normativity is grounded in our aims is commonly labelled epistemic instrumentalism in epistemology. See Lockard (2013) for discussion. I also discuss epistemic instrumentalism in Côté-Bouchard (2015).
} 
form a belief about whether P. But this is implausible. For one thing, this seems to suggest that we necessarily form our beliefs intentionally or voluntarily. But even doxastic voluntarists admit that many of our beliefs-e.g. perceptual beliefs-are not formed intentionally. For another, our beliefs are sometimes formed unconsciously via processes like wishful thinking, self-deception, or delusion. But it is unclear how I can count as intending to believe the truth when I form beliefs in that way. Not only do these processes operate sub-personally and without my awareness, they are also characterized precisely by a lack of concern for the truth.

On another reading, for someone to aim at something is for her to want or care about that thing. Possessed aims, in other words, are desires. On this reading, the personal interpretation of the aim of belief is that necessarily, whenever we form or revise a belief about whether $\mathrm{P}$, we want to believe the truth about whether $\mathrm{P}$. However, this is also implausible. It is clearly possible for agents to lack the desire to believe the truth about whether $\mathrm{P}$, even in forming a belief about whether $\mathrm{P} .{ }^{26}$

First, people sometimes form true beliefs despite wanting to avoid learning the truth about the matter at hand. Suppose you recorded last night's football game and want to avoid knowing the score until you watch it tonight, but you inadvertently see the score on a newspaper left open in the bus. You immediately and automatically form the true belief that your favourite team lost as a result even though you wanted to avoid knowing the truth about that question at that moment.

Second, people sometimes form beliefs despite being completely indifferent about the matter at hand. Suppose you do not care at all about obscure and random historical facts, but cannot help but hear a historian on the radio telling the story of a 17th century Londoner named John. You do not care at all about this trivial and obscure story. It is not remotely interesting to you. Nevertheless, as a result of hearing bits of the story, you cannot help but form the belief that at least one Londoner named John was born on February 6th 1626. Moreover, you form that belief despite not caring at all about whether someone with that name was really born in London on that date.

Third, phenomena such as wishful thinking, delusion, and self-deception are also problematic for the desire construal. While these processes can (unconsciously) produce genuine beliefs, it is hard to see how they could always involve caring for the truth. If anything, such processes seem to be characterized precisely by a lack of concern for the truth. Suppose you are ill and despite your conclusively evidence to the contrary, you become convinced that you will certainly recover from your illness. You form that belief not as the result of deliberating about whether you will recover, but instead unconsciously as the result of your fear of dying and your inability to cope with the thought of not recovering. It is hard to see how you can be said to have wanted to believe the truth about your health in forming that belief. What you wanted was rather that the world be a certain a way and that strong motivation then caused you to believe that things really are that way.

So it seems clear that we sometimes form the belief that $\mathrm{P}$ without intending or wanting to believe the truth about whether P. Is there another possible reading of the

${ }^{26}$ See Kelly (2003) for discussion. 
personal interpretation? That is, in cases where we form the belief that $\mathrm{P}$ despite neither wanting nor intending to believe the truth about whether $\mathrm{P}$, can we still be said to aim at or to have the aim of believing the truth about whether P?

Intuitively, it does not seem so. In many of these cases, the formation of the belief is something that automatically happens to us whether we like or not. In the football example, my inadvertently seeing the score in the paper immediately forces upon me the belief that my team lost. But why think that I am aiming at believing the truth if it is forced upon me like that? The mechanisms that cause me to immediately form that belief might very well be directed towards producing that true belief. But it is hard to see why the aim of these mechanisms would thereby also be my aim. Compare this with our bodily functions. Livers aim at filtering toxic impurities out the blood and healthy livers constantly do so without healthy people being aware of it. But it would be strange to say that healthy people-including those who have no idea what livers do or those who do not want a properly functioning liver-thereby always aim at filtering toxic impurities out of their blood.

Moreover, even if there were a sense in which we could be said to aim at $\varphi$-ing without intending or wanting to $\varphi$, it is far from clear that such a weak kind of aim could ground genuinely normative reasons. After all, reasons internalists typically ground such reasons specifically in desires. For example, Alan H. Goldman introduces reasons internalism as the claim that "[a] reason is not a reason intrinsically: in itself it cannot demand on pain of irrationality that agents be motivated by it. It is because agents have certain concerns or desires that they have reasons" (Goldman 2009, 9). Similarly, according to Mark Schroeder, "[f]or $R$ to be a reason for $X$ to do $A$ is for there to be some $p$ such that $X$ has a desire whose object is $p$, and the truth of $R$ is part of what explains why $X$ 's doing $A$ promotes $p$." (Schroeder 2007, 59) The point is that for many reasons internalists, if you do not care about $\varphi$-ing and if $\varphi$-ing would not promote anything you care about, then there really is no reason for you to $\varphi$.

One potential solution to these problems is to construe the personal constitutive aim of belief not as a particular aim that we have every time we form or revise a belief, but rather as a global or general aim of truth. On this alternative reading, even though agents can sometimes lack the desire to believe the truth about particular matters, they necessarily have the general desire that their beliefs be true. But this is no more plausible. The idea that everyone necessarily cares about the truth in that way seems overly optimistic and naïve. Surely, some people do not have such a general concern for the truth. At the very least, there is nothing incoherent with the idea of an agent who, for example, only wants her important and nontrivial beliefs to be true, or who wants that her beliefs be true, except in cases where believing the truth would lead to overwhelmingly bad results.

For all these reasons, the personal version of Epistemic Constitutivism fails as well. Since the personal interpretation of the aim of belief thesis is untenable, it cannot plausibly ground Epistemic Normativity. 


\section{The normativist interpretation}

On a final, normativist interpretation, the claim that belief constitutively aims at that truth is a metaphor for the claim that belief is constitutively governed by a norm of truth. ${ }^{27}$ As Ralph Wedgwood explains:

It is often claimed that beliefs aim at the truth. Indeed, this claim has often been thought to express an essential or constitutive feature of belief. But this claim is obviously not literally true. Beliefs are not little archers armed with little bows and arrows: they do not literally "aim" at anything. The claim must be interpreted as a metaphor. I propose to interpret this claim as a normative claim-roughly, as the claim that a belief is correct if and only if the proposition believed is true (Wedgwood 2002, 267).

As the last passage indicates, a popular candidate for the constitutive truth norm of belief is the following:

(TN) A belief is correct if and only if it is true.

Using TN as our example, we can therefore characterize the normativist version of the aim of belief thesis as the claim that belief is constitutively governed by the epistemic norm TN. That is, part of what it is for something to be a belief is for it to be correct if and only if it is true. Can this version of the aim of belief thesis ground Epistemic Normativity?

Recall that according to Epistemic Normativity, there is necessarily a good reason to do as epistemic norms say. Therefore, Epistemic Normativity only follows from the normativist aim of belief thesis if:

\section{(RTN) There is necessarily a good reason to believe correctly.}

Once again, constitutivists must say that this further normative claim is also true in virtue of the fact that belief aims at truth. To ground RTN in something else-e.g. the final or instrumental value of correct beliefs-would be to ground Epistemic Normativity in these facts about value and not in the fact that belief aims at truth. But can the normativist aim of belief thesis ground RTN?

It is far from clear. Recall the distinction between norm-relativity and normativity. While any norm trivially sets a standard relative to which certain things are correct or incorrect, this leaves open the normative question whether there is any good reason to conform to that norm. So to posit a constitutive norm of belief is not yet to say that there is a good reason to do as that norm says. As an analogy, writing the same number twice in one of the columns of a Sudoku grid is incorrect relative to the constitutive norms or rules of Sudoku. Yet there might be no good reason for me to avoid that incorrect Sudoku move. Similarly, we can very well accept that according to TN, a belief is correct if and only if it is true, but still ask

\footnotetext{
${ }^{27}$ For the claim that belief has a constitutive norm, see Brandom (1994), Adler (2002), Wedgwood (2002), Boghossian (2003), Shah (2003), Engel (2004), Millar (2004), Gibbard (2005), Shah and Velleman (2005), Zangwill (2005), Whiting (2010), Littlejohn (2012, 2013), and Nolfi (2015). See also McHugh and Whiting (2014) and Fassio (2015) for overviews of issues surrounding normativism.
} 
whether there is any good reason to have correct beliefs. Maybe there is necessarily such a reason. But the point is that the sole fact that it is correct in a certain respect does not entail that there is.

It won't help to point out that belief, unlike other norm-governed activities like games, is something agents necessarily engage in. First, as I pointed out above, unavoidability is not normatively relevant. We can very well ask the normative question about norm-governed activities that are unavoidable for agents. Consider the activity of using a language. Languages have constitutive norms or rules. Moreover, using a language is arguably unavoidable and perhaps even constitutive of what it is to be a human agent. Yet rules of languages are often considered to lack necessary normative force. ${ }^{28}$ Second, although belief or the faculty of belief might be constitutive of agency, always believing correctly is not. So even if being constitutive of agency is normatively relevant, good reasons to always believe correctly do not follow. At best, it vindicates reasons to merely have beliefs or to have some correct beliefs.

Another possible move for the normativist epistemic constitutivist is to build genuine normativity directly in the constitutive norm of belief. On this interpretation, 'correct' and 'incorrect' in TN are genuinely normative notions, i.e. notions that already entail good reasons. It is constitutive of belief, in other words, that we should - in the genuinely normative sense of 'should'-believe something if and only if it is true.

Aside from its seemingly question-begging character, the main problem with this move is that it also means abandoning epistemic constitutivism. EC is a strategy for grounding or explaining Epistemic Normativity. For EC, it is because belief constitutively aims at truth that epistemic norms necessarily have normative force. But on the suggestion I am now considering, the aim of belief thesis does not ground or explain Epistemic Normativity. It just is Epistemic Normativity. If TN is genuinely normative, then what grounds TN? The answer cannot be the aim of belief thesis since $\mathrm{TN}$ just is the aim of belief thesis according to normativism. Hence, if it is to be grounded at all, it must be grounded in something beyond the aim of belief, which makes EC false.

But perhaps TN does not need grounding. Perhaps it is a sui generis or brute fact that we should - in the genuinely normative sense-believe something if and only if it is true. This alternative option is no more helpful for EC however. First, epistemic constitutivism is the claim that the aim of belief thesis grounds or explains Epistemic Normativity. But if TN (and thus Epistemic Normativity) is a sui generis fact, then the aim of belief does not ground it since nothing grounds it. So adopting this version of normativism means abandoning the project or concern that gave rise to the constitutivist strategy in the first place, namely that of explaining in virtue of what epistemic norms have necessary normative force.

Second, making this claim also means abandoning the central motivation for EC. As I explained above, normative error theorists think that genuine inescapable normativity does not exist because it requires the existence of mysterious nonnatural

\footnotetext{
${ }^{28}$ See Hattiangadi (2007) for discussion.
} 
facts. The main advantage of constitutivism was that it promised to vindicate inescapable normativity without positing such facts. However, this is not what the present version of normativism attempts to do. All it says is that beliefs just are genuinely normative entities and that this is a sui generis or brute fact. But this does not address the worry that such entities and facts are mysterious. For the error theorist, this version of normativism would simply mean that beliefs are also mysterious nonnatural entities and thus that there are no such things. If normativism claims that Epistemic Normativity is a sui generis or brute fact, then it is best seen not as an alternative to nonnaturalism, but as an instance of it.

I therefore conclude that the normativist version of epistemic constitutivism is not promising either. The claim that truth is the constitutive norm of belief cannot plausibly ground Epistemic Normativity.

\section{Conclusion}

According to Epistemic Normativity, epistemic norms necessarily entail genuinely normative reasons. According to epistemic constitutivism (EC), Epistemic Normativity is true ultimately in virtue of the fact that belief constitutively aims at truth. I examined various versions of EC based on the main possible interpretations of the aim of belief thesis. I argued that none of these versions of the thesis can plausibly ground Epistemic normativity. ${ }^{29}$ I therefore conclude that epistemic constitutivism is hopeless as a strategy for grounding Epistemic Normativity.

Of course, this does not mean that Epistemic Normativity is false. Perhaps conforming to epistemic norms necessarily leads to intrinsically good things. Or perhaps Epistemic Normativity is a sui generis or brute fact. However, if you are moved by the central motivation for EC and if EC is indeed hopeless, then Epistemic Normativity becomes more problematic. Recall that EC promised to accomplish what neither the nonnaturalist nor the error theorist think can be done, namely vindicating necessary normativity without positing nonnatural facts. But if $\mathrm{EC}$ is false and if nonnatural facts are off the table for you, then you might have to conclude that Epistemic Normativity must be abandoned.

Would you then have to go for an epistemic error theory and conclude that there are no truths and facts about what we epistemically should believe? Only if you think that our concept of an epistemic norm is that of a norm with necessary normative force. But this is not the only option. Perhaps Epistemic Normativity is false not (or not only) because necessary normativity does not exist, but rather because our concept of an epistemic norm is not, after all, that of a norm that

\footnotetext{
29 Another potential worry with EC is that it may prove too much. It is widely that young infants and non-human animals can have beliefs. But if beliefs constitutively aim at truth and if, as EC claims, this fact suffices to grounds Epistemic Normativity, it seems to follow that there is necessarily a good reason even for infants and animals to conform to epistemic norms. However, many think that such beings cannot be subject to genuine normativity and reasons. It is not clear, after all, that infants and animals can $\varphi$ for reasons. Relatedly, it seems strange to say, for example, that dogs should not believe against their evidence or that infants should suspend judgment about whether $\mathrm{P}$ if they have no evidence for or against $P$.
} 
necessarily entails good reasons. That is, perhaps epistemic norms have the same kind of normative authority as e.g. norms of etiquette, fashion, games, and the like. If this is right, then there can still be facts about what we epistemically should believe. But just like facts about what we should do according to etiquette, they are not genuinely normative facts.

Acknowledgments I would like to thank Maria Alvarez, Terence Cuneo, Nick French, Elizabeth Fricker, Alex Marcoci, an anonymous referee from Philosophical Studies and audiences from the University of Edinburgh, UC Berkeley, and the 2015 London Spring Graduate Conference for their help and feedback. Thanks also to the Social Sciences and Humanities Research Council of Canada for its support.

Open Access This article is distributed under the terms of the Creative Commons Attribution 4.0 International License (http://creativecommons.org/licenses/by/4.0/), which permits unrestricted use, distribution, and reproduction in any medium, provided you give appropriate credit to the original author(s) and the source, provide a link to the Creative Commons license, and indicate if changes were made.

\section{References}

Adler, J. (2002). Belief's own ethics. Cambridge: MIT Press.

Bertea, S. (2013). Constitutivism and normativity: A qualified defence. Philosophical Explorations, $16(1), 81-95$.

Bird, A. (2007). Justified judging. Philosophy and Phenomenological Research, 74(1), 81-110.

Boghossian, P. A. (2003). The normativity of content. Philosophical Issues, 13(1), 31-45.

Brandom, R. (1994). Making it explicit: reasoning, representing, and discursive commitment. Cambridge: Harvard University Press.

Broome, J. (2013). Rationality through reasoning. London: Wiley-Blackwell.

Burge, T. (2003). Perceptual entitlement. Philosophy and Phenomenological Research, 67(3), 503-548.

Côté-Bouchard, C. (2015). Epistemic instrumentalism and the too few reasons objection. International Journal of Philosophical Studies, 23(3), 337-355.

Cuneo, T. (2007). The normative web: An argument for moral realism. Oxford: Oxford University Press.

Engel, P. (2004). Truth and the aim of belief. In D. Gillies (Ed.), Laws and models in science (pp. 77-97). London: King's College Publications.

Enoch, D. (2006). Agency, shmagency: Why normativity won't come from what is constitutive of action. Philosophical Review, 115(2), 169-198.

Enoch, D. (2011). Taking morality seriously: A defense of robust realism. Oxford: Oxford University Press.

Fassio, D. (2015). The Aim of Belief. The Internet Encyclopedia of Philosophy. http://www.iep.utm.edu/ beli-aim/. Accessed 12 March 2016.

Ferrero, L. (2009). Constitutivism and the inescapability of agency. Oxford Studies in Metaethics, 4, 303-333.

Finlay, S. (2014). Confusion of tongues: A theory of normative language. Oxford: OUP.

Fitzpatrick, W. (2008). Robust ethical realism, non-naturalism, and normativity. Oxford Studies in Metaethics, 3, 159-205.

Foot, P. (1972). Morality as a system of hypothetical imperatives. Philosophical Review, 81(3), 305-316.

Garner, R. T. (1990). On the genuine queerness of moral properties and facts. Australasian Journal of Philosophy, 68(2), 137-146.

Gibbard, A. (2005). Truth and correct belief. Philosophical Issues, 15(1), 338-350.

Goldman, A. H. (2009). Reasons from within: Desires and values. Oxford: Oxford University Press.

Grimm, S. R. (2009). Epistemic normativity. In A. Haddock, A. Millar, \& D. Pritchard (Eds.), Epistemic value. Oxford: Oxford University Press.

Hattiangadi, A. (2007). Oughts and thoughts: Rule-following and the normativity of content. Oxford: Oxford University Press. 
Huemer, M. (2007). Moore's paradox and the norm of belief. In S. Nuccetelli \& G. Seay (Eds.), Themes from G.E. Moore. Oxford: Oxford University Press.

Joyce, R. (2001). The myth of morality. Cambridge: Cambridge University Press.

Katsafanas, P. (2013). Agency and the foundations of ethics: Nietzschean constitutivism. Oxford: Oxford University Press.

Katsafanas, P. (Forthcoming). Constitutivism about practical reasons. In D. Star (Ed.), Oxford handbook of reasons and normativity. Oxford: Oxford University Press.

Kelly, T. (2003). Epistemic rationality as instrumental rationality: A critique. Philosophy and Phenomenological Research, 66(3), 612-640.

Kolodny, N. (2005). Why be rational? Mind, 114(455), 509-563.

Korsgaard, C. M. (1996). The sources of normativity. Cambridge: Cambridge University Press.

Korsgaard, C. M. (2008). The constitution of agency: Essays on practical reason and moral psychology. Oxford: Oxford University Press.

Korsgaard, C. M. (2009). Self-constitution: Agency, identity, and integrity. Oxford: Oxford University Press.

Littlejohn, C. (2012). Justification and the truth-connection. Cambridge: Cambridge University Press.

Littlejohn, C. (2013). The Russellian retreat. Proceedings of the Aristotelian Society, 113(3pt3), 293-320.

Littlejohn, C., \& Turri, J. (Eds.). (2014). Epistemic norms: New essays on action, belief and assertion. Oxford: Oxford University Press.

Lockard, M. (2013). Epistemic instrumentalism. Synthese, 190(9), 1701-1718.

Mackie, J. L. (1977). Ethics: Inventing right and wrong. London: Penguin.

Markovits, J. (2014). Moral reason. Oxford: OUP.

McHugh, C. (2011). What do we aim at when we believe? Dialectica, 65(3), 369-392.

McHugh, C. (2012). Belief and aims. Philosophical Studies, 160(3), 425-439.

McHugh, C., \& Whiting, D. (2014). The normativity of belief. Analysis, 74(4), 698-713.

McPherson, T. (2011). Against quietist normative realism. Philosophical Studies, 154(2), 223-240.

Millar, A. (2004). Understanding people: Normativity and rationalizing explanation. New York, NY: Oxford University Press.

Moore, G. E. (1903). Principia ethica. Mineola: Dover Publications.

Nolfi, K. (2015). How to be a normativist about the nature of belief. Pacific Philosophical Quarterly, 96(2), 181-204.

O'Hagan, E. (2004). Practical identity and the constitution of agency. Journal of Value Inquiry, 38(1), 49-59.

O’Hagan, E. (2005). Belief, normativity and the constitution of agency. Philosophical Explorations, 8(1), 39-52.

Olson, J. (2014). Moral error theory: History, critique, defence. Oxford: OUP.

Papineau, D (2013). There are no norms of belief. In T. Chan (Ed.), The Aim of Belief. Oxford: Oxford University Press.

Parfit, D. (2011). On what matters. Oxford: Oxford University Press.

Peacocke, C. (1999). Being known. Oxford: Oxford University Press.

Railton, P. (1994). Truth, reason, and the regulation of belief. Philosophical Issues, 5, 71-93.

Railton, P. (1997). On the hypothetical and non-hypothetical in reasoning about belief and action. In G. Cullity \& B. N. Gaut (Eds.), Ethics and practical reason (pp. 53-79). Oxford: Oxford University Press.

Rosati, C. S. (2003). Agency and the open question argument. Ethics, 113(3), 490-527.

Raz, J. (2011). From normativity to responsibility. Oxford: Oxford University Press.

Scanlon, T. (1998). What we owe to each other. Harvard: Belknap Press, Harvard University Press.

Schroeder, M. (2007). Slaves of the passions. Oxford: Oxford University Press.

Shafer-Laudau, R. (2003). Moral realism: A defence. Oxford: Oxford University Press.

Shah, N. (2003). How truth governs belief. Philosophical Review, 112(4), 447-482.

Shah, N., \& Velleman, J. D. (2005). Doxastic deliberation. Philosophical Review, 114(4), 497-534.

Skorupski, J. (2010). The Domain of reasons. Oxford: Oxford University Press.

Smith, M. (1994). The moral problem. London: Blackwell.

Steglich-Petersen, A. (2006). No norm needed: On the aim of belief. Philosophical Quarterly, 56(225), 499-516.

Steglich-Petersen, A. (2009). Weighing the aim of belief. Philosophical Studies, 145(3), 395-405.

Sutton, J. (2007). Without justification. Cambridge: MIT Press.

Sylvan, K. (2014). On the normativity of epistemic rationality. Ph.D. dissertation. Rutgers University. 
Tiffany, E. (2007). Deflationary normative pluralism. Canadian Journal of Philosophy, 37(5), $231-262$. Tubert, A. (2010). Constitutive arguments. Philosophy Compass, 5(8), 656-666.

Tubert, A. (2011). Korsgaard's constitutive arguments and the principles of practical reason. Philosophical Quarterly, 61(243), 343-362.

Vahid, H. (2006). Aiming at truth: Doxastic vs. epistemic goals. Philosophical Studies, 131(2), 303-335.

Velleman, D. (2000). The possibility of practical reason. Oxford: Oxford University Press.

Wallace, J. (2001). Normativity, commitment, and instrumental reason. Philosophers' Imprint, 1(4), $1-26$.

Wedgwood, R. (2002). The aim of belief. Philosophical Perspectives, 16(16), 267-297.

Wedgwood, R. (2007). The nature of normativity. Oxford: Oxford University Press.

Whiting, D. (2010). Should I believe the truth? Dialectica, 64(2), 213-224.

Whiting, D. (2012). Does belief aim (only) at the truth? Pacific Philosophical Quarterly, 93(2), 279-300.

Wiland, E. (2012). Reasons. Vancouver: Continuum.

Williams, B. (1973). Deciding to believe. In B. Williams (Ed.), Problems of the self (pp. 136-151). Cambridge: Cambridge University Press.

Williams, B. (1979). Internal and external reasons. In R. Harrison (Ed.), Rational action (pp. 101-113). Cambridge: Cambridge University Press.

Williamson, T. (2000). Knowledge and its limits. Oxford: Oxford University Press.

Worsnip, A. (Forthcoming). Moral reasons, epistemic reasons, and rationality. Philosophical Quarterly. doi: $10.1093 / \mathrm{pq} / \mathrm{pqv} 084$.

Zangwill, N. (2005). The normativity of the mental. Philosophical Explorations, 8(1), 1-19. 